УДК 004.588:811.1

DOI:

Юлія Матвіїв-Лозинська, кандидат педагогічних наук, доцент кафедри іноземних мов Національний університет "Львівська політехніка"

\title{
ОСОБЛИВОСТІ ЗАСТОСУВАННЯ ВІРТУАЛЬНОГО НАВЧАЛЬНОГО СЕРЕДОВИЩА У КОНТЕКСТІ ІНШОМОВНОЇ ПІДГОТОВКИ ФАХІВЦІВ
}

У статті розглянуто суть віртуального навчального середовища у закладах вищої освіти. Підтверджено, щу у підготовці фахівців важливе місце займає електронне навчально-методичне забезпечення. Проведено аналіз теоретичних праџь вітчизняних фахівців, який свідчить, шуо у контексті дослідження не існує однозначного тлумачення сутності поняття віртуального навчального середовища. Представлено віртуальне навчальне середовище у контексті іншомовної підготовки фахівців. Наведено зразок комплексу віртуального навчального середовища з іноземноїмови для майбутніх фахівців гуманітарних спеціальностей.

Ключові слова: вища освіта; заклади вищої освіти; віртуальне навчальне середовище; іншомовна підготовка; фахівці.

Табл. 2. Лім. 6.

Yuliya Matviyiv-Lozynska, Ph.D.(Pedagogy), Associate Professor of the Foreign Languages Department Lviv Polytechnic National University

\section{FEATURES OFTHE VIRTUAL LEARNING ENVIRONMENT APPLYING IN THE CONTEXT OF FOREIGN LANGUAGES TRAINING OF SPECIALISTS}

The article considers virtual learning environment in higher educational establishments. The development of information communications technology enables to use its sources in educational process. The electronic educational and methodical materials are of great importance in higher education nowadays. It helps lecturers and students conduct and master educational materials accordingly, especially in distant education. The virtual learning environment has its advantages, such as: saving the time, flexibility, cooperation within the campus, possibility to exchange information, automatic integration of students' results into the information system. The analysis of theoretical works of national specialists indicates that there is no unique interpretation of the virtual educational environment concept under research. Future specialists of the humanitarian profile need profound knowledge of foreign languages, especially English, to succeed both in career and everyday life. Thus, the initial aim of the educational process in higher educational establishments is to provide students with proper level of education to implement in future. The author highlights virtual learning environment applying in the foreign language lessons for future specialists of the humanitarian profile. The attention in the article is paid to the main aspects of the language studying, in particular: vocabulary, reading, grammar, speaking and writing. Due to the volume of the virtual learning environment for the whole course of the subject the article reveals only one of the topics, that is "Globalization". The samples of the relevant tasks according to the topic of the curriculum with proper explanation are provided. The value of the article is its practical aspect. It can be used by teachers and students during English lessons. It simplifies the educational process for all participants. Teachers have visual aids to conduct the lesson properly and students have possibility to revise the materials given and to do extra tasks to improve their knowledge and skills.

Keywords: higher education; higher educational establishment; virtual learning environment; foreign languages training; specialists.

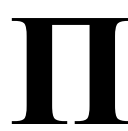
остановка проблеми. На сучасному етапі розвитку освіти і науки спостерігаються прогресивні зміни. Це стосується змістового наповнення освітніх програм та їх практичного впровадження в навчальний процес. Розробка освітніх програм все частіше супроводжується інформаційним забезпеченням, що дозволяє ефективно впроваджувати програму на практиці, застосовувати iii в умовах дистанційного навчання, самостійного опрацювання матеріалу студентами, а також для повторення пройденого матеріалу на заняттях.
3 метою якісного засвоєння поданого на заняттях матеріалу в контексті іншомовної підготовки фахівців ефективно впроваджується в навчальний процес розроблене інформаційне забезпечення у вигляді віртуального навчального середовища.

Аналіз основних досліджень і публікацій. Проблематика віртуального навчального середовища відносно нова, проте вже певною мірою досліджувана науковцями. Існує певна невизначеність у трактуванні даного поняття, оскільки достеменно науковцями не було 


\section{ОСОБЛИВОСТІ ЗАСТОСУВАННЯ ВІРТУАЛЬНОГО НАВЧАЛЬНОГО СЕРЕДОВИЩА У КОНТЕКСТІ ІНШОМОВНОЇПІДГОТОВКИ ФАХІВЦІВ}

виокремлено єдиної галузі, якої стосується це явище. Науковці, такі як: Т. Вакалюк, В. Ковальчук, В. Кухаренко, Р. Гуревич, А. Рибачук, О. Самойленко, Е. Сарафанюк, В. Терещук та інші займалися дослідженням даної проблематики через призму застосування віртуальної реальності у навчальному процесі. Більшість дослідників схиляються до думки, що віртуальне навчальне середовище як система було розроблено з метою підтримки навчального процесу у дистанційній освіті, де наголошується саме на навчанні, а не на управлінні навчальним процесом [6].

Особливості застосування віртуального навчального середовища на практиці для підготовки фахівців досліджувалися науковцями, які описували дану проблематику, проте в контексті іншомовної підготовки фахівців гуманітарних спеціальностей не були предметом спеціального дослідження.

Постановка завдання. Метою даної статті $\epsilon$ визначити особливості віртуального навчального середовища в контексті іншомовної підготовки та презентувати певні елементи його розробки для фахівців гуманітарних спеціальностей.

Виклад основного матеріалу дослідження. Навчальний процес закладів вищої освіти модернізується через використання інформаційних технологій. Створення якісного інформаційного забезпечення навчальних дисциплін спрощує роботу викладача i полегшує студентам опрацювання нового матеріалу. Невід'ємною складовою навчального процесу виступає дистанційне навчання, яке є неможливим без використання Інтернет-ресурсів та комп'ютерних технологій. Застосування прогресивних технологій у навчанні забезпечують інтерактивну взаємодію між учасниками навчального процесу, а саме - між викладачем та студентом. Така взаємодія відображає позитивні результати для всіх учасників навчального процесу і дозволяє навчатися студентам різних вікових груп.

3 метою забезпечення ефективної взаємодії між викладачем і студентом було впроваджено у практику використання віртуального навчального середовища. Віртуальне навчальне середовище це система програмного забезпечення, створена 3 метою реалізації процесу дистанційного навчання, де передбачено власне навчання студентів як суб'єктів навчального процесу. Дана система буде ефективно функціонувати за наявності Інтернет-мережі, в якій $є$ можливим процес організації навчання та його оцінювання. В межах розробленого ВНС студенти мають можливість користуватися не лише спеціально підготовленими викладачами навчальними матеріалами, але й автентичними аудіо- та відеоресурсами, блогами, тощо на задану тематику.

За інформацією взятою 3 джерел Вікіпедії використання ВНС у закладах вищої освіти передбачає виконання наступних завдань:

- економія часу педагогічного складу, зменшення витрат на послуги інструкторів;

- надання інструкцій у гнучкий спосіб студентам, не лімітуючи їх у часі та місці навчання;

- надання інструкцій у спосіб, звичний для сучасного веб-орієнтованого покоління студентів;

- сприяння співробітництву та поширенню інформації між різними кампусами або коледжами;

- надання можливості обміну матеріалами між різними курсами;

- забезпечення автоматичної інтеграції результатів навчання студентів до інформаційної системи кампусів [1].

В контексті іншомовної підготовки майбутні фахівці гуманітарних спеціальностей потребують постійної практики застосування набутих знань та умінь. Використання мовних виразів та кліше на заняттях з іноземної мови потрібно доповнювати самостійним опрацюванням матеріалу. Це важко втілити студентами самостійно, адже необхідно шукати типові завдання на задану тематику і доповнювати набуті знання практичним застосуванням. На допомогу студентам у вирішенні даної проблеми приходить розроблений викладачами-предметниками комплекс ВНС, де вміщується вичерпна інформація на задану тематику з практичними завданнями, що дає змогу закріпити вивчений на заняттях матеріал та додатково повправлятися у його застосуванні.

В поданій статті ми звертаємо увагу на зразок розробленого ВНС для фахівців гуманітарних спеціальностей в контексті іншомовної підготовки, а саме через використання іноземної мови. Кожен урок подано у вигляді основних аспектів: вокабуляр, читання, граматика, говоріння, писання.

На основі розробленого навчального посібника Р.Д. Карамишевої та ін. [3] розглянемо одну з розроблених тем ВНС “Globalization” у контексті іншомовної підготовки фахівців 3 міжнародних відносин. Перед початком розгляду лексики 3 даної теми подаємо запитання, які зорієнтовують студентів, про що буде йти мова на занятті.

Task 1. Discuss the following questions:

- What images spring to mind when you hear the word "globalization"?

- What are the good and bad things about globalization? 


\section{ОСОБЛИВОСТІ ЗАСТОСУВАННЯ ВІРТУАЛЬНОГОНАВЧАЛЬНОГО СЕРЕДОВИЩА У КОНТЕКСТІІНШОМОВНОӤ ПДГОТОВКИФАХІВЦІВ}

- Do you think it is possible to ignore globalization?

Студенти висловлюють свою думку з даних питань іноземною мовою, обговорюють у групі, дискутують, діляться набутими знаннями. Подані питання породжують низку наступних запитань більшу зацікавленість у обговоренні. Оскільки тема непроста, необхідно опрацювати фахову лексику.

Task 2. Memorize the essential vocabulary and translate the sentences containing it:

(1) abundance (велика кількість, поширеність) - a large quantity of something. e.g. One quality the team possessed in abundance was fighting spirit.

(2) crucial (вирішальний, критичний) extremely important because everything else depends on it. e.g. This aid money is crucial to the government's economic policies.(3)

encompass (охоплювати) - to include a wide range of ideas, subjects, etc. e.g. The study encompasses the social, political, and economic aspects of the situation.

(4) pervasiveness (поширеність) - the quality of filling or spreading throughout. e.g. Such pervasiveness also creates challenges of effectively managing this data and ensuring it's secure.

Подаємо лише декілька лексичних одиниць, щоб показати яким чином вводимо вокабуляр до теми 3 використанням прикладів застосування активної лексики у реченнях. На основі поданої лексики формуємо текст для читання на задану тему, якому передують запитання для групи студентів, щоб наштовхнути на обговорення. Після тексту подаємо завдання, які студенти виконують на основі прочитаного матеріалу.

Task 3. Read the text to answer the following questions:

- Is it easy to define the term globalization?

- When did the term globalization begin to be widely used?

- How does globalization influence time and boundaries?

- How are the modern technologies connected with globalization?

\section{Globalization}

Globalization became the trendiest craze in international relations (IR) theory at the turn of the century. What is globalization? That's a good question, and one that scholars in and out of IR have had difficulty grappling with. Globalization has been described as "a term which can refer to anything from the Internet to a hamburger". That's because theorists disagree on just about everything regarding "globalization". They disagree about when "globalization" started. Some date its beginning after
World War II, while others argue it is as old as capitalism itself. They disagree about what it expresses (economic, geographic, social, political, or cultural phenomena) and whether or not one or more of these phenomena should be emphasized over the others. And they disagree about whether "globalization" is a process, an ideology ("globalism"), or a "state of being" ("globality"). Given all these disagreements, it is not sur-prising that one theorist described "globalization" as simply "a floating sign of many different problematics".

Task 4. Answer the following questions basing on the text above.

1.What is globalization?

2.When was the beginning of globalization?

3.What does Steger's definition of globalization highlight?

4. What does globalization disrupt?

5.Do scholars agree on the only one definition of globalization?

Task 5. Translate the following sentences into English.

1. Вивчення глобалізації охоплює аналіз соціальних, політичних та економічних процесів. 2. Деякі вчені датують початок глобалізації періодом Другої світової війни, в той час як інші стверджують, що цей процес розпочався значно швидше. 3. Вчені розходяться в думках про те, чи глобалізація є процесом, ідеологією, чи станом. 4. Глобалізація руйнує просторові та часові межі, збільшуючи темпи життя. 5. Одні теоретики вважають, що глобалізація є позитивним процесом, інші вважають, що за своєю суттю вона “погана”, а треті стверджують, що вона може мати як позитивні, так і негативні сторони.

Task 6. Read the text and find the English equivalents of the following phrases:

1. Культурні відмінності; 2. Міжнародна торгівля наркотиками; 3. Глобальні ринкові сили; 4. Характеристики, які можна визначити; 5. Раціоналізував і виробництво, і розподіл; 6. Зростаюче усвідомлення; 7. Майже миттєвий; 8. Що формують майбутнє; 9. Чинити свій вплив; 10. Спілкування через територіальні межі.

Task 7. Fill in the necessary prepositions in the text:

Steger's definition of globalization also highlights connections ... the local and the global. ... an interconnected world, distant events and forces can have a pro-found impact ... local endeavours. Unexpected connections frequently emerge, some of which may be experienced positively ... most who are affected ... the connec-tion, and others of which have devastating consequences ... one or more affected groups. The link between consumer demand 


\section{ОСОБЛИВОСТІ ЗАСТОСУВАННЯ ВІРТУАЛЬНОГО НАВЧАЛЬНОГО СЕРЕДОВИЩА У КОНТЕКСТІІНШОМОВНОЇ ПІДОТОВКИ ФАХІВЦІВ}

... electronic devices and a bloody civil war ... the Democratic Republic of Congo (DRC) is one such tragic example. This connection ... war and electronics emerged because the DRC holds percent of the world's coltan reserves. Though not a household word, coltan has become one of the world's most valued materials. Refined coltan produces tantalum, a metal powder used ... the production of capacitors, which are critical components in electronic devices like cell phones and laptop computers. One might think that the abundance of such a valuable mineral would benefit the DRC, but, unfortunately, coltan has been mined by warring rebel groups and used to finance a devastating civil war. The conflict, which started ... 1998, has claimed more than 4 million lives.

Після завдань на основі читання подаємо граматичний аспект рідною мовою 3 метою повного розуміння теми студентами.

Task 8. Look through the information on the Passive Voice:

Якщо підмет означає особу або предмет, на які спрямовано дію іншої особи або предмета, то дієслово-присудок вживається в Пасивному стані. Усі часові форми пасивного стану утворюються з допоміжного дієслова to be у відповідному часі та the Past Participle основного дієслова [4]:

Task 9. Open the brackets using the correct form of verb in Passive Voice:

Globalization processes, including the rise of transnational corporations, the ubiquity of Western popular culture, and the ease of long-distance, high-

speed travel, have transformed societies, some of the differences among them 1. (to erase) and similar environments in many places around the globe 2. (to create). Indeed, more similarities 3 . (to share) by most major cities around the world than ever before, and many of these similarities are Western, such as the pervasiveness of American fast food, Western business suits, Hollywood movies, and the English language.

Наприкінці кожного уроку подаються завдання для вдосконалення комунікативних навичок. Тематика спонукає студентів до комунікації та висловлення своєї думки використовуючи вивчений лексичний та граматичний матеріал. Нижче наведені завдання можна використовувати як теми для написання ессе студентами.

Task 10. Read the quotes below and try to explain them in your own words, do you agree with them?

"Globalization, as defined by rich people like us, is a very nice thing... you are talking about the Internet, you are talking about cell phones, you are talking about computers. This doesn't affect two-thirds of the people of the world".

(Jimmy Carter)

"One day there will be no borders, no boundaries, no flags and no countries and the only passport will be the heart".

(Carlos Santana)

"It has been said that arguing against globalization is like arguing against the laws of gravity".

(Kofi Annan)

Таблиця 1.

Порівняння активного та пасивного стану

\begin{tabular}{|c|c|}
\hline The Active Voice & The Passive Voice \\
\hline $\begin{array}{l}\text { The writer publishes novels } \\
\text { every year. - Письменник друкує романи кожного } \\
\text { року. }\end{array}$ & $\begin{array}{l}\text { The novels are published by the writer every year. - } \\
\text { Романи друкуються письменником кожного року. }\end{array}$ \\
\hline $\begin{array}{l}\text { The pupil read the book last week. - Учень прочитав } \\
\text { книжку минулого тижня. }\end{array}$ & $\begin{array}{l}\text { The book was read by the pupil last week. - Книжка } \\
\text { була прочитана учнем минулого тижня. }\end{array}$ \\
\hline They laughed at him. - Вони сміялися над ним. & He was laughed at. - Над ним сміялися. \\
\hline We sent for the doctor. - Ми послали за лікарем. & The doctor was sent for. - За лікарем послали. \\
\hline $\begin{array}{l}\text { They listened to him with interest. - Ми слухали його } \\
3 \text { цікавістю. }\end{array}$ & $\begin{array}{l}\text { He was listened to with interest. - Його слухали } 3 \\
\text { цікавістю. }\end{array}$ \\
\hline
\end{tabular}

Таблиця 2.

Часові форми дісслова в пасивному стані

\begin{tabular}{|c|c|c|c|}
\hline & Indefinite & Continuous & Perfect \\
\hline Present & The house is built. & The house is being built. & The house has been built. \\
\hline Past & The house was built. & $\begin{array}{l}\text { The house was being } \\
\text { built. }\end{array}$ & The house had been built. \\
\hline Future & The house will be built. & - & $\begin{array}{l}\text { The house will have been } \\
\text { built. }\end{array}$ \\
\hline Future-in-the-Past & $\begin{array}{l}\text { I said the house would be } \\
\text { built. }\end{array}$ & - & - \\
\hline
\end{tabular}




\section{ОСОБЛИВОСТІ ЗАСТОСУВАННЯ ВІРТУАЛЬНОГОНАВЧАЛЬНОГО СЕРЕДОВИЩА У КОНТЕКСТІІНШОМОВНОЇПІДГОТОВКИ ФАХІВЦІВ}

3 вищенаведених завдань ВНС для майбутніх фахівців у контексті іншомовної підготовки можна зрозуміти, що аспекти вивчення іноземної мови охоплюються повністю та дозволяють студентам підвищити свій рівень володіння мовою з поданої теми. Окрім поданих зразків завдань викладачі додатково забезпечують використання на заняттях автентичних аудіо- та відеоматеріалів по темах, що дозволяє зробити заняття цікавішим, продуктивнішим та досягнути кінцевої мети навчального процесу - оволодіти знаннями, уміннями та навичками.

Висновки. Навчальний процес у закладах вищої освіти передбачає застосування різних форм та методів, які здатні зацікавити студентську аудиторію та значно підвищити рівень знань. Сучасна молодь звертає увагу на ті знання, вміння та навики, які практично можна застосувати у подальшому житті. Іноземна мова належить до тих дисциплін, для вивчення яких не потрібно додаткової мотивації на теперішній час. III використовують всюди - у побуті, на роботі, під час подорожей тощо. 3 метою вдосконалення рівня володіння іноземною мовою необхідно, щоб заняття були цікавими, насиченими та продуктивними. Звичайно, викладач повинен спланувати кожне заняття таким чином, щоб студенти з задоволенням їх відвідували, черпали знання та ретельно готувалися. Не завжди тематика програмного матеріалу є цікавою для студентів, тому розроблений комплекс ВНС дозволяє викладачеві варіювати навчальний процес на занятті, пропонувати інтерактивні завдання та спрямовувати хід заняття відповідно до зацікавлень та уподобань студентів. Вище наведений зразок завдань ВНС для студентів демонструє цікавий матеріал по темах програми, який охоплює всі аспекти вивчення мови та активно апробується на заняттях з іноземної мови.

До перспектив подальших розвідок в даному напрямку відносимо дослідження аудіота відео наповненості ВНС з метою якісного володіння іноземною мовою студентами гуманітарних спеціальностей в контексті іншомовної підготовки.

\section{ЛІТЕРАТУРА}

1. Вільна енциклопедія “Вікіпедія". URL:https:// uk.wikipedia.org/wiki/

2. Гуревич Р. С. Перспективи освіти в інформаційному суспільстві. Актуальні проблеми виробничих та інформаційних технологій, економіки i фундаментальних наук: Зб. наук. праць. Вінниця Планер, 2005. Вип. 2. 546 с.

3. Карамишева Р.Д., Карамишева, І.Д., Мукан, Н.В. та ін. Іноземна мова професійного спрямування (англійська мова для фахівців з міжнародних відносин):Навчальний посібник / За ред. Н.В. Мукан, Я.Б. Турчин. Львів: Видавництво Львівської політехніки, 2014. 206 с.

4. Пасивний стан (The Passive Voice). URL: https:// school-2.com/theory/english/verb/4.php

5. Рибачук А. В. Вплив комп’ютерних технологій на інтенсифікацію навчання у вищій школі. Сучасні інформаційні технології та інноваційні методики навчання у підготовці фахівців: методологія, теорія, досвід, проблеми: Зб. наук, праць. Київ-Вінниця: ДОВ "Вінниця", 2006. Вип. 10. С. $442-445$.

6. Терещук В. Віртуальне навчальне середовище: сугність та психолого- педагогічні умови його створення. Науковий вісник Ужгородського національного університету. Серія :Педагогіка. Соціальна робота. 2016. Вип. 1. С. 279-283. URL: http://nbuv.gov.ua/UJRN/ Nvuuped_2016_1_71.

\section{REFERENCES}

1. Vilna entsyklopediia "Vikipediia" [Free encyclopedia "Wikipedia"]. [Electronic resource]. Available at: https:// uk.wikipedia.org/wiki/ [in Ukrainian].

2. Hurevych, R. S. (2005). Perspektyvy osvity v informatsiinomu suspilstvi [Education perspectives in information society]. Topical issues of production and information technologies, economy and fundamental sciences: Collection of scientific works. Vinnytsia Planer, Vol. 2, 546 p. [in Ukrainian].

3. Karamysheva, R.D., Karamysheva, I.D. \& Mukan, N.V. et al. (2014). Inozemna mova profesiinoho spriamuvannia (anhliiska mova dlia fakhivtsiv $\mathrm{z}$ mizhnarodnykh vidnosyn) [Foreign language for specific purposes (English for specialists in international relations)]. Educational manual. (Eds.). Mukan, N.V. \& Turchyn, Ya.B. Lviv, 206 p. [in Ukrainian].

4. Pasyvnyi stan [The Passive Voice]. [Electronic resource]. Available at: https://school-2.com/theory/ english/verb/4.php [in Ukrainian].

5. Rybachuk A. V. (2006). Vplyv kompiuternykh tekhnolohii na intensyfikatsiiu navchannia $u$ vyshchii shkoli [Computer technologies influence on the education intensification in higher school]. Modern information technologies and innovative methodics of education in specialists' training: methodology, theory, experience, problems: Collection of scientific works. Kyiv-Vinnytsia: DOV "Vinnytsia", Vol. 10, pp. 442 - 445. [in Ukrainian].

6. Tereshchuk, V. (2016). Virtualne navchalne seredovyshche: sutnist ta psykholoho- pedahohichni umovy yoho stvorennia [Virtual learning environment: the essence and psychological and pedagogical conditions of its creating]. Scientific herald of Uzhgorod National University. Series : Pedagogy. Social work. Vol. 1, pp. 279 283. Available at: http://nbuv.gov.ua/UJRN/ Nvuuped_2016_1_71.[in Ukrainian].

Стаття надійшла до редакції 30.01.2019 